\title{
RESEARCH
}

Open Access

\section{Hydrochemical aspects of high-temperature aquifer storage in carbonaceous aquifers: evaluation of a field study}

\author{
Martina Ueckert ${ }^{*}$ (1) and Thomas Baumann (1)
}

\author{
*Correspondence: \\ martina.ueckert@tum.de \\ Institute of Hydrochemistry, \\ Technical University \\ of Munich, Marchioninistr. 17, \\ 81377 Munich, Germany
}

\begin{abstract}
Aquifer thermal energy storage systems in the sediments of the Upper Jurassic in the north-eastern part of the Bavarian Molasse Basin seem to be feasible in terms of the hydrogeological and hydrochemical setting. This study presents unique results from the first large-scale high-temperature heat storage test in these sediments and a hydrogeochemical model based and validated with the field data. The test was run in a single well setting with five injection and production cycles and temperatures from 65 to $110^{\circ} \mathrm{C}$. The flow rates were $15 \mathrm{~L} / \mathrm{s}$. Due to the very high transmissivity, mixing and density-driven flow have been observed and confirmed by hydrochemical analyses. Mixing was quantified using the natural contrast of the sodium ion concentrations as a natural tracer. Using the mixing ratios, a deduction of the effects of mixing on the temperature of the produced water was possible and a correction was applied to the recovered energy. The temperatures of the produced water show that $48 \%$ of the injected energy was recovered during the field test and the remaining energy is "charging" the aquifer. A kinetic hydrogeochemical model including 1D-transport was developed with PhreeqC to quantify the reactions in the reservoir and calibrated with the hydrochemical data of the first and second phase of the field test. The other three phases of the field test were used for validation. Model and measurement data were in excellent agreement and show significant dissolution of carbonates which can be attributed to an undersaturation of the water as it equilibrates with the matrix at lower temperatures. Based on field data from the single well test and the calibrated model, the operation of an ATES system was designed and simulated. Model results indicate that a doublet setting for ATES cannot be operated for more than a few cycles, regardless of the conditioning methods. In a triplet system, however, the time frame for successful operation can be extended to decades.
\end{abstract}

Keywords: Aquifer thermal energy storage, Heat storage test, Hydrogeochemistry, Bavarian Molasse Basin, Carbonaceous Malm aquifer, Hydrogeochemical modelling, PhreeqC 


\section{Introduction}

Combined heat and power plants (CHP) are efficient and environmentally friendly because excess heat produced during power generation is used for heating purposes. While the power demand remains rather constant throughout the year, the heat demand shows seasonal variations. In a worst-case scenario, the heat production in winter is not sufficient, and the power production in summer has to be ramped down because the excess heat cannot be released to the environment. Therefore, storage of excess heat from a CHP is highly beneficial from an economic and an ecological point of view. One storage solution providing the required storage capacity and power is aquifer thermal energy storage (ATES) (Schout et al. 2014). In a typical setting, water from an aquifer is produced, heated up by excess heat from the CHP and then injected through a second borehole back into the aquifer (Fig. 1).

ATES requires a high permeability of the aquifer matrix because the energy is stored in the fluid (Lee 2010; Stober and Bucher 2014). The transport of water in suitable settings is much faster compared to heat conduction in the rock matrix, and the heat capacity of water exceeds the heat capacity of the rock matrix by a factor of about five (Stober et al. 2014). Once the rock matrix has the same temperature as the injected water, losses of thermal energy are limited by heat conduction at the top and bottom boundaries, mixing at the fringes of the injected water volume, and a potential drift of the injected water with the natural groundwater flow (Ueckert et al. 2016). Therefore, caprocks and basements with very low permeability and low heat capacity and an aquifer with high permeability and high porosity as well as negligible groundwater flow make up an ideal setting (Andersson 2007; Lee 2013). However, knowledge about the performance of ATES in reactive reservoirs at high injection temperatures $\left(T>100{ }^{\circ} \mathrm{C}\right)$ is still limited (Drijver et al. 2012; Hartog et al. 2013; Sanner et al. 2005).

The carbonate rocks of the Upper Jurassic in the Molasse Basin provide high transmissivity and are covered with tight caprock. Thus, two main requirements for ATES are met. However, reactions in the aquifer cannot be neglected and may become the limiting process of the operation. Recent studies have shown significant dissolution at the injection wells in carbonates, caused by the temperature change and also by a different

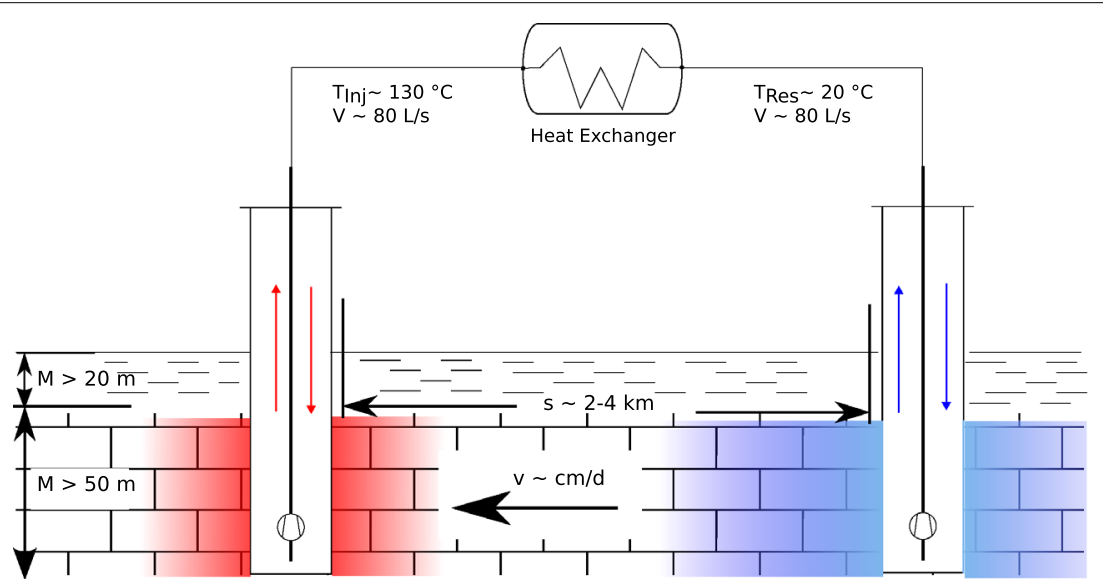

Fig. 1 Setup of a typical heat storage system 
lithostratigraphic setting (limestone instead of dolomite) (Baumann et al. 2017). Potential problems of ATES operations in carbonate aquifers are mainly caused by the disruption of the carbonic acid equilibrium resulting in precipitation and dissolution processes, which are limiting the economical benefit and can cause safety issues (Kranz et al. 2015; Lee 2013; Perlinger et al. 1987).

The ATES at the study site will receive excess heat from seven CHPs $\left(P_{\mathrm{E}}=31 \mathrm{MW}, P_{\text {th }}\right.$ $=27 \mathrm{MW})$. With a temperature of the water in the aquifer of around $22{ }^{\circ} \mathrm{C}$ and a peak temperature of the injected water of $130^{\circ} \mathrm{C}$, approx. $60 \mathrm{~kg} / \mathrm{s}$ have to be stored to accommodate all excess thermal energy. It is evident that only an ATES with high specific yield offers enough storage capacity (Lee 2013) for this site. Preliminary geological and hydrogeological site assessment and geophysical soundings indicated that the carbonaceous aquifer of the Upper Jurassic at the proposed site most likely offers these conditions (Dorsch and Pletl 2012; Fritzer et al. 2014).

For the first time in the Molasse Basin and as one of very few international projects, a large scale ATES test was performed within the presented study, which was funded by the Bavarian State Ministry for Economic Affairs and the BMW Group. The project combines field data with modelling and is supported by laboratory experiments. We conclude with a hydrogeochemical simulation of an aquifer thermal energy storage system which is based on the numerical model calibrated with data from the field test.

\section{Materials and methods}

\section{Site description}

The site is located in the north-eastern part of the Bavarian Molasse Basin. At the research borehole, the topmost quaternary sediments consist of sand and gravel and reach a thickness of almost $20 \mathrm{~m}$. Below, a sequence of tertiary sands and silts reaches down to $100 \mathrm{~m}$ true vertical depth (TVD). The underlying clay- and marlstones, interspersed with calcium carbonate rich marlstones and clayey marlstones, add to total thickness of $110 \mathrm{~m}$ (244 m TVD) and are impermeable. The top of the reservoir was reached at $244 \mathrm{~m}$ TVD. The carbonates of the Upper Jurassic start with $20 \mathrm{~m}$ (264 m TVD) limestones followed by dolomites and dolomitic breccia. Drilling problems and core losses occurred between 297 and 397 m TVD and indicate a carstified structure or a heavily disrupted joint system (Bartels et al. 2015). With a total depth of $472.9 \mathrm{~m} \mathrm{TVD}$, the research borehole did not reach the crystalline basement.

The artesian aquifer is flowing freely with up to $19.4 \mathrm{~L} / \mathrm{s}$. The calculated transmissivity was of $10^{-1} \mathrm{~m}^{2} / \mathrm{s}$. The flowmeter logs indicate a strong vertical heterogeneity of the permeability.

\section{Setup of the heat storage test}

The heat storage test was performed in a single well setting at the research borehole and was planned as push-pull test. A schematic of the setting is given in Fig. 2. The heat storage plant was designed by the authors, planned by Gammel Engineering, Abensberg, Germany, and constructed by Lausser $\mathrm{GmbH}$, Rattiszell, Germany.

In the absence of a second well in the reservoir, tap water was heated and injected in five stages. The first test $(=$ stage 0$)$ was performed after the borehole reached a depth 


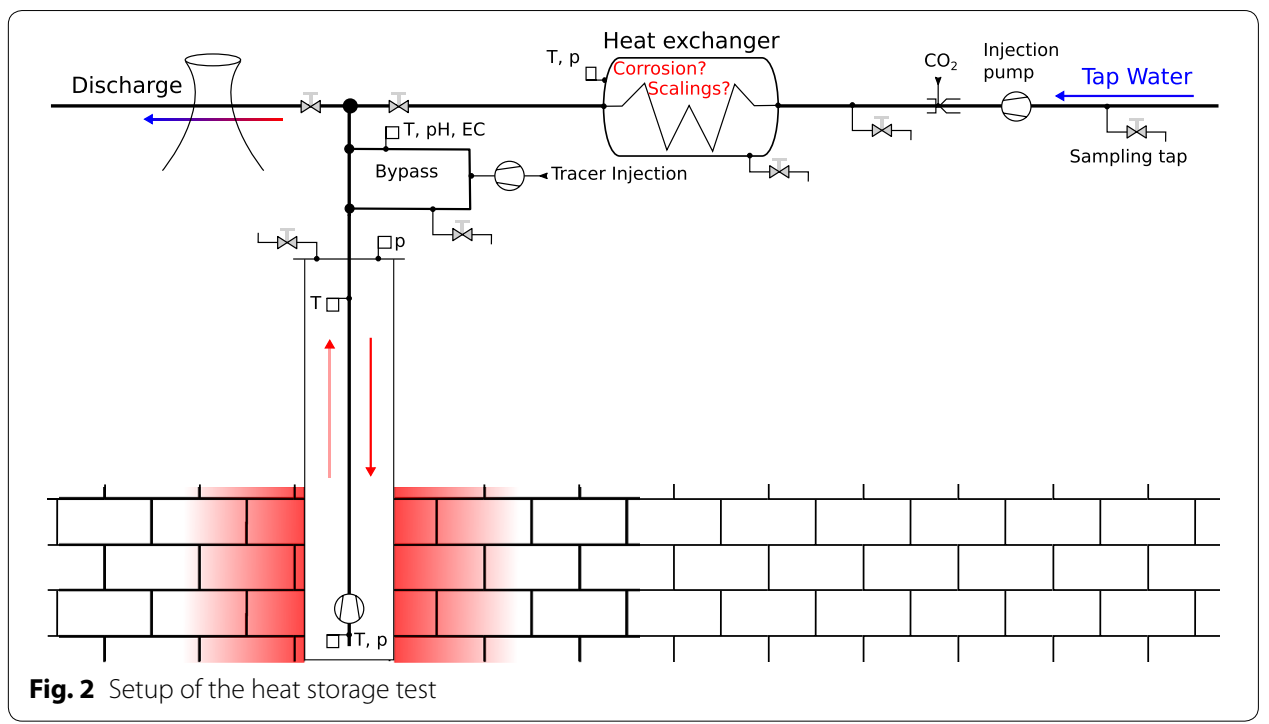

Table 1 Breakdown of the heat storage test

\begin{tabular}{|c|c|c|c|c|c|c|}
\hline Date & Time & Running time (h) & Stage & $\dot{V}_{\text {inj. }}(\mathrm{L} / \mathrm{s})$ & $\dot{V}_{\text {prod. }}(\mathrm{L} / \mathrm{s})$ & Temp. $\left({ }^{\circ} \mathrm{C}\right)$ \\
\hline 2014-10-15 & $22: 20$ & $48: 00$ & 0 & 15 & & 65 \\
\hline 2014-10-17 & $22: 20$ & $60: 00$ & 0 & & 15 & \\
\hline 2014-11-24 & $15: 15$ & $60: 00$ & 1 & 15 & & 80 \\
\hline 2014-11-27 & 03:15 & $47: 45$ & 1 & & 15 & \\
\hline 2014-11-29 & 03:00 & $48: 00$ & 2 & 15 & & 90 \\
\hline 2014-12-01 & 03:00 & $36: 00$ & 2 & & 15 & \\
\hline 2014-12-02 & $15: 00$ & $48: 10$ & 3 & 15 & & 110 \\
\hline 2014-12-04 & $15: 10$ & $35: 50$ & 3 & & 15 & \\
\hline 2014-12-06 & 03:00 & $48: 00$ & 4 & 15 & & 110 \\
\hline 2014-12-08 & 03:00 & $96: 00$ & 4 & & 15 & \\
\hline 2014-12-12 & 03:00 & End & & & & \\
\hline
\end{tabular}

of 297 m TVD after losses of drilling mud were encountered. Stages 1-4 followed after completion of the borehole and a pumping test.

$\mathrm{CO}_{2}$ (food grade, Air Liquide) was added to the tap water using a CS-nozzle to prevent scalings in the heat exchanger during heating. The concentration of $\mathrm{CO}_{2}$ was calculated using PhreeqC (see below). The hot water was injected through the casing using a rotary pump at a rate of $15 \mathrm{~L} / \mathrm{s}$. Immediately after injection, the pump was switched off and production started. As the aquifer was freely flowing, the flow rate was regulated by a valve. The parameters of the tests are given in Table 1.

Produced water passed a degassing station, several cooling tanks, and reaction tanks to regulate the $\mathrm{pH}$ value, remove $\mathrm{H}_{2} \mathrm{~S}$, and to oxygenize the water, if necessary, before the water was released into a ditch leading to the nearby river.

\section{Sampling and analysis}

On-site sensors were mounted to a bypass loop just outside the immediate safety perimeter (flow length $\approx 10 \mathrm{~m}$ from the well head). Here, $\mathrm{pH}$, temperature, and electrical 
conductivity (InPro 4800i resp. 7100i, M300, MettlerToledo, Germany) were recorded at time intervals of $1 \mathrm{~min}$. Pressure heads, temperatures, $\mathrm{pH}$ and EC were also recorded by Geoservice $\mathrm{GmbH}$, Georgsdorf, Germany. Redox-potential and oxygen content were measured discontinuously using electrodes (Seven Go Duo, Seven Go Pro, Mettler Toledo, Germany).

Samples were taken in regular intervals (10-60 $\mathrm{min}$ ) during injection and production at the sampling port mounted to the bypass. An on-site liquid cooler was used at temperatures above $90{ }^{\circ} \mathrm{C}$. The concentrations of sodium, potassium, calcium, and magnesium ions were determined on-site in a lab container by ion chromatography (881 Compact IC pro, Metrohm, Germany) equipped with a C4-150 column (Metrohm, Germany). Alkalinity was quantified by titration. The concentrations of chloride, fluoride, nitrate, and sulfate ions were measured at the main laboratory using ion chromatography with EC detector (IC 25, IonPac AS9-HC column, Dionex). Total sulfide in water was precipitated on-site with $10 \mathrm{~mL}$ zinc acetate $(2 \%)$. The concentration of the precipitated zinc sulfide was measured with the methylene blue colorimetric method (Deutsches Institut für Normierung (DIN) 1995) using a spectrophotometer (Double Beam UV-190, Shimadzu).

\section{Calculation of the energy balance}

Recent measurements of the temperatures at the well head and in the reservoir suggest that the temperature losses are less than $2-4 \mathrm{~K}$ for geothermal wells in the Central Molasse Basin (depth 2-4 km). Given the low depth of the reservoir (244 m TVD), temperature losses during production were considered negligible and a simplified energy balance based on the temperature development of the produced water seems to be acceptable. For this purpose, the injected and produced thermal energy $q$ was calculated for each stage with Eq. (1).

$$
q=\int \mathrm{d} t T(t) \cdot c \cdot \rho \cdot \dot{V}
$$

Here, $T(t)$ is the temperature at time $t, c$ denotes the specific heat capacity, $\rho$ the fluid density, and $\dot{V}$ the flow rate.

\section{Description of the chemical system}

Previous studies (Baumann et al. 2017; Mayrhofer et al. 2014) have shown that the reactions in the reservoirs in the Upper Jurassic can be described using a simplified chemical system: the solution is described by the dissolved ions (sodium, potassium, calcium, magnesium, chloride, sulfate and sulfide, and bicarbonate) together with the $\mathrm{pH}$, redox potential, and the gas loading and composition. The reservoir matrix is implemented as pure mineral phases dolomite and calcite in varying ratios. Additionally, we defined a magnesium-rich calcite $\left(\mathrm{Ca}_{0.8} \mathrm{Mg}_{0.2} \mathrm{CO}_{3}\right)$. This simplification reduces the reactions to the lime-carbonic-acid equilibrium (Appelo and Postma 2005). The dissolution of calcite in this system can be written as Eqs. (2)-(4).

All three processes occur in parallel at the water-solid interface (Plummer et al. 1978):

$$
\mathrm{CaCO}_{3}+\mathrm{H}^{+} \rightleftharpoons \mathrm{Ca}^{2+}+\mathrm{HCO}_{3}^{-}
$$




$$
\begin{aligned}
& \mathrm{CaCO}_{3}+\mathrm{H}_{2} \mathrm{CO}_{3}^{*} \rightleftharpoons \mathrm{Ca}^{2+}+2 \mathrm{HCO}_{3}^{-} \\
& \mathrm{CaCO}_{3} \rightleftharpoons \mathrm{Ca}^{2+}+\mathrm{CO}_{3}^{2-}
\end{aligned}
$$

The calcite reaction rate that was implemented in the PhreeqC model was taken from (Plummer et al. 1978) and reads:

$$
r=k_{1} \cdot\left[\mathrm{H}^{+}\right]+k_{2} \cdot\left[\mathrm{H}_{2} \mathrm{CO}_{3}^{*}\right]+k_{3} \cdot\left[\mathrm{H}_{2} \mathrm{O}\right]-k_{4}\left[\mathrm{Ca}^{2+}\right]\left[\mathrm{HCO}_{3}^{-}\right]
$$

with the reaction rate $r$, the rate constants $k_{1}, k_{2}, k_{3}$ and $k_{4}$ and the activities of the reactants.

These rate constants for calcite were also used as initial guesses for the rate constants for magnesium-rich calcite. The later calibration of model did not require a change of the rate constants.

The dissolution of dolomite can be written as (Plummer et al. 1978):

$$
\begin{aligned}
& \mathrm{CaMg}\left(\mathrm{CO}_{3}\right)_{2}+2 \mathrm{H}^{+} \rightleftharpoons \mathrm{Mg}^{2+}+\mathrm{Ca}^{2+}+2 \mathrm{HCO}_{3}^{-} \\
& \mathrm{CaMg}\left(\mathrm{CO}_{3}\right)_{2}+\mathrm{H}_{2} \mathrm{CO}_{3}^{*} \rightleftharpoons \mathrm{Mg}^{2+}+\mathrm{Ca}^{2+}+4 \mathrm{HCO}_{3}^{-} \\
& \mathrm{CaMg}\left(\mathrm{CO}_{3}\right)_{2} \rightleftharpoons \mathrm{Mg}^{2+}+\mathrm{Ca}^{2+}+2 \mathrm{CO}_{3}^{2-}
\end{aligned}
$$

The implemented reaction rates for dolomite are based on the transition state theory (Pokrovsky and Schott 2001):

$$
R=\left[k_{\mathrm{CO}_{3}} \cdot\left\{>\mathrm{CO}_{3} \mathrm{H}^{0}\right\}^{2}+k_{\mathrm{Mg}} \cdot\left\{>\mathrm{MgOH}_{2}^{+}\right\}^{1.9}\right] \cdot\left(1-\exp \left(\frac{-1.9 A}{R T}\right)\right)
$$

At $\mathrm{pH}$ values above 6 and an ionic strength of $100 \mathrm{mM} \mathrm{Eq.} \mathrm{(10)} \mathrm{becomes:}$

$$
R=k_{\mathrm{Mg}}^{*} \cdot\left\{\frac{K_{\mathrm{CO}_{3}}^{*} \cdot K_{\mathrm{Ca}}^{*}}{K_{\mathrm{CO}_{3}}^{*} \cdot K_{\mathrm{Ca}}^{*}+K_{\mathrm{Ca}}^{*} \cdot a_{\mathrm{CO}_{3}}^{2-}+a_{\mathrm{CO}_{3}}^{2-} \cdot a_{\mathrm{Ca}^{2+}}}\right\}^{1.9} \cdot\left[1-\left(\frac{Q}{K_{\mathrm{Sp}}^{0}}\right)^{1.9}\right]
$$

with the concentration on the surface $\{>i\}$ in $\mathrm{mol} / \mathrm{m}^{2}$, the reaction affinity $A$, the constants $k_{\mathrm{CO}_{3}}, k_{\mathrm{Mg}}, k_{\mathrm{Mg}}^{*}, K_{\mathrm{CO}_{3}}^{*}, K_{\mathrm{Ca}}^{*}$, the activities of the reactants and the saturation index for dolomite, written as $\frac{Q}{K_{\mathrm{Sp}}^{0}}$.

\section{Hydrogeochemical simulation of the heat storage test}

The hydrogeochemical model of the test site was developed using PhreeqC, v.3.3.9 and the stock database (phreeqc.dat, v. 3.3.9) (Parkhurst and Appelo 2013). Figure 3 shows the conceptual model and the simulation checkpoints.

The first step for all simulations was to calculate the composition of the water under reservoir conditions. Checkpoint 1 is the chemical composition of the water after degassing to ambient conditions and cooling. All chemical analyses and gas analyses are provided for this point and form the initial solutions in the model. However, gas analysis and $\mathrm{pH}$ value are already affected by the sampling procedure. For backcalculation, we implemented the degassing and cooling steps into the model. At first we introduced the measured concentrations of the cations and anions and added the measured gases nitrogen, methane, and ethane (= checkpoint 1$)$. The non-reactive representations of these gases ( $\mathrm{Mtg}(\mathrm{g})$ instead of $\mathrm{CH}_{4}(\mathrm{~g}), \mathrm{Ntg}(\mathrm{g})$ instead of $\mathrm{N}_{2}(\mathrm{~g})$ ) 


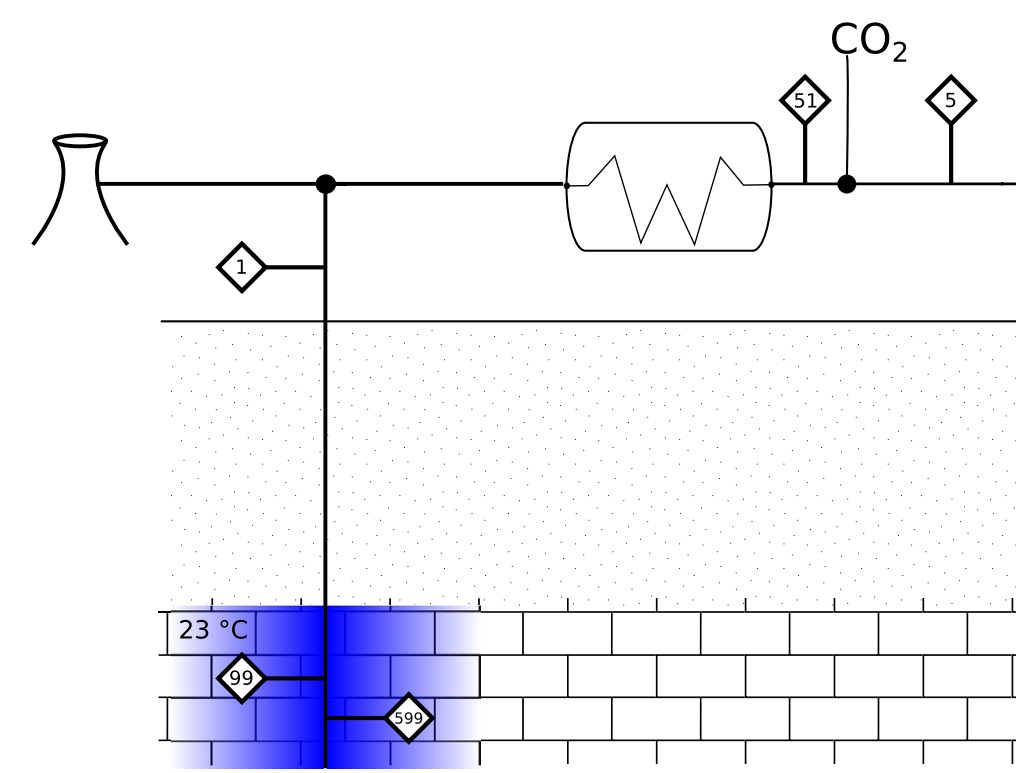

Fig. 3 Conceptual model of the heat storage test including simulation checkpoints

were used to prevent reactions with the gases during degassing. The rationale behind this simplification was that the reaction rates of the gases are slow compared to the degassing process. Thermodynamic parameters for ethane were taken from the Lawrence-Livermore-National-Labs database (llnl.dat) and the Peng-Robinson parameters were taken from PREOS.xls (Lira 1997). From this solution the gases methane, ethane, nitrogen, water vapor, $\mathrm{CO}_{2}$, and $\mathrm{H}_{2} \mathrm{~S}$ were allowed to equilibrate at a pressure and temperature matching the experimental setup for sampling and analysis. A manual optimization was done to minimize the differences between measured and calculated values for the concentration of the gases, the $\mathrm{pH}$ value after degassing, the alkalinity after degassing and to target a SI of 0 for dolomite which is the main matrix constituent. Sensitivity analyses and brute-force optimization runs showed that the error surface of the residuals has no local minima and that the manual optimization is robust and yields unique results. The result of the backcalculation procedure is the hydrochemical and gas composition of the water at reservoir conditions (= checkpoint 99) (see also Baumann et al. 2017).

To simulate the heat storage test, we introduced the tap water with its measured composition at checkpoint 5 and add $\mathrm{CO}_{2}$ at checkpoint 51 . The reactions in the reservoir during the heat storage test were implemented as kinetic reactions using the hydrochemical system described above. Reaction rates for calcite and dolomite have also been experimentally verified in autoclave experiments with aquifer matrix from the test site. We used calcite reaction rates after Plummer et al. (1978) and after Gautelier et al. (2007) for dolomite, which were in good agreement with published values for this setup (Ueckert 2016).

The injection and production of water and the propagation in the reservoir were implemented as 1D radially symmetric transport with defined residence times per cell. One stagnant cell per mobile cell was implemented to account for diffusion 


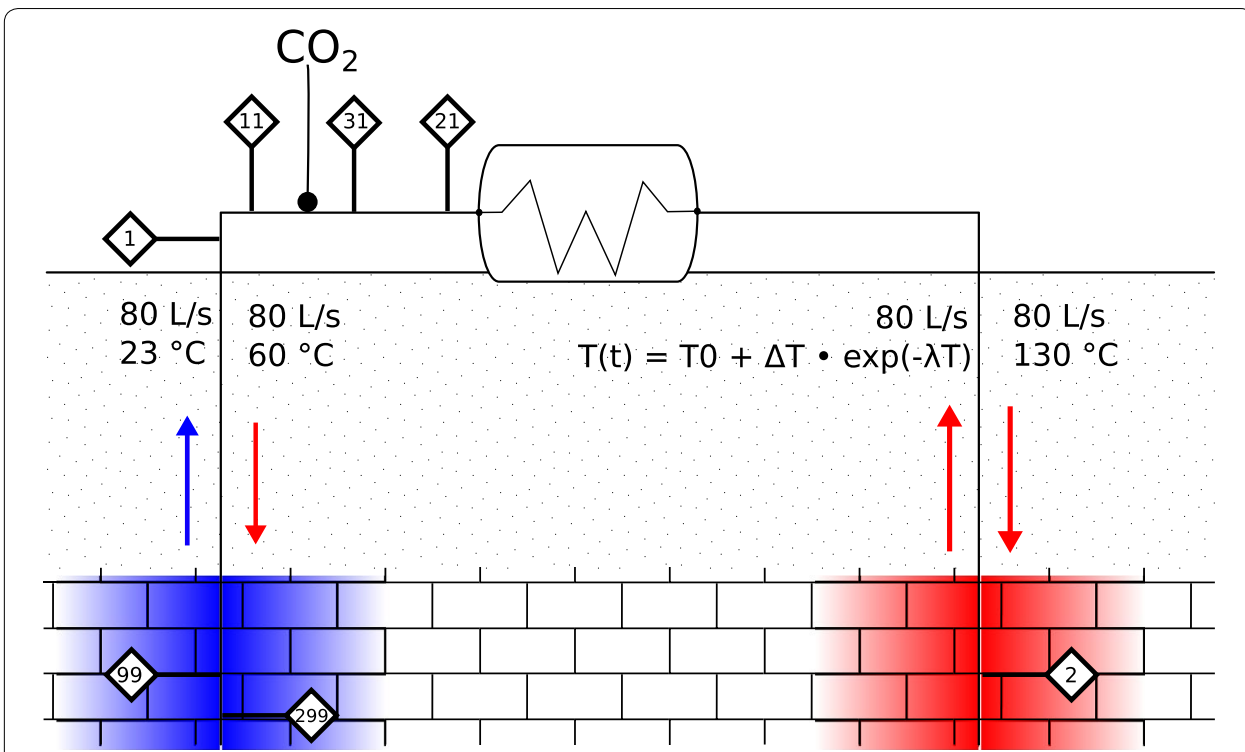

Fig. 4 Conceptual model of an ATES as doublet system including simulation checkpoints

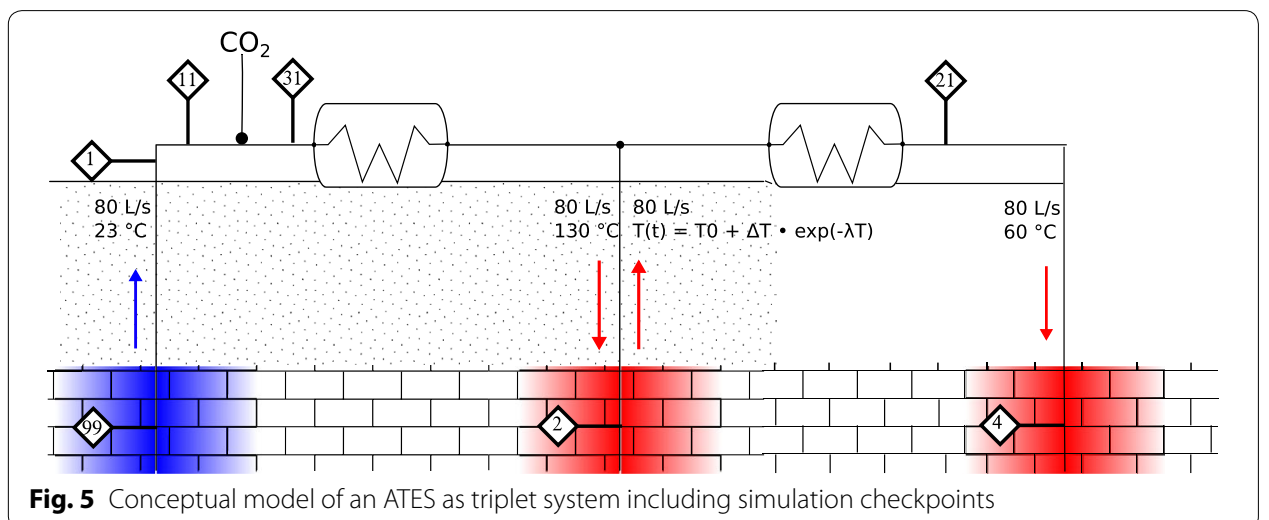

processes from the main flow paths into the matrix. We considered $2 \%$ of the total porosity (6 \% (Bartels et al. 2015)) to be mobile and $98 \%$ to be immobile (= matrix porosity). The diffusion coefficient was taken from Parkhurst and Appelo (2013) $\left(=1 \times 10^{-9} \mathrm{~m}^{2} / \mathrm{s}\right)$. At Checkpoint 599 the reaction of the hot tap water with the aquifer matrix and fluid is taking place.

\section{Hydrogeochemical simulation of the ATES system}

The forward simulation of the operation of an ATES system at the test site is based on the model calibrated and validated with data from the field test and follows the conceptual model shown in Fig. 4. The extension to a triplet system is shown in Fig. 5.

During operation, the length of the injection and production cycles is long compared to the reaction kinetics. This allows switching back to an equilibrium model. One other significant difference is the hydrochemical composition of the heated fluid: while tap water was used in the heat storage test, reservoir water will be the working fluid during operation (= checkpoint 99$)$. The water on the surface (= checkpoint 1$)$ will be heated to 
$130{ }^{\circ} \mathrm{C}$ and $\mathrm{CO}_{2}$ is added (= checkpoint 11 ) in several steps until the saturation indices were within $0.1-0.2$ (= checkpoint 31$)$.

In the simulated doublet system, the water is injected into the aquifer at the hot well and equilibrates with the aquifer matrix (= checkpoint 2 ). The water is then produced and the remaining heat is extracted to $60^{\circ} \mathrm{C}$ (= checkpoint 21). That solution is injected into the aquifer at the cold well and equilibrates with the aquifer matrix (= checkpoint 299) and becomes the working fluid for the simulation of the next cycle.

In the simulated triplet system, the water after heat extraction (checkpoint 21) is injected into a third well and equilibrates with the aquifer matrix there (= checkpoint 4). Instead of a direct movement of the water masses between cold well and hot well, the next storage cycle will once again use water from cold well and not the injected water from the third well. The water from the third injection well is slowly flowing to the cold well instead.

\section{Results and discussion}

The hydrochemical composition of the tap and aquifer water is given in Table 2.

The reservoir water contains $915 \mathrm{mg} / \mathrm{L}$ total dissolved solids (TDS) and is a $\mathrm{Na}-$ $\mathrm{HCO}_{3}-\mathrm{Cl}$-type water. Sodium ion concentrations are enriched compared to the chloride ion concentrations, which suggests ion exchange on clay minerals. The $\mathrm{Ca} / \mathrm{Mg}$ ratio is close to one and points to a mainly dolomitic reservoir matrix (Langmuir 1971; Mayrhofer et al. 2014). This indicates that the limestone encountered in the upper part of the borehole (Bartels et al. 2015) has likely a very limited spatial extent or is not permanently part of the flow regime. The gas volume was $45 \mathrm{~mL} / \mathrm{L}$ (at normal conditions). It consists of methane (60 vol\%), nitrogen (36 vol\%) and $\mathrm{CO}_{2}(4 \mathrm{vol} \%)$. The calculated degassing pressure at $22{ }^{\circ} \mathrm{C}$ is $2.93 \mathrm{bar}$ and increases to 6.94 bar at $130{ }^{\circ} \mathrm{C}$. The calculated partial pressure of $\mathrm{CO}_{2}$ at $22^{\circ} \mathrm{C}$ is 0.04 bar and increases to 0.17 bar at $130{ }^{\circ} \mathrm{C}$.

Table 2 Hydrochemical composition of the fluids used in the heat storage test (ND = not determined)

\begin{tabular}{llll}
\hline Parameter & Unit & Tap & Reservoir \\
\hline $\mathrm{EC}$ & $\mathrm{mS} / \mathrm{cm}$ & 0.615 & 1.18 \\
$\mathrm{pH}$ & & 6.92 & 7.07 \\
$\mathrm{Temp}$ & ${ }^{\circ} \mathrm{C}$ & 13.1 & 22.7 \\
$\mathrm{TDS}$ & $\mathrm{mg} / \mathrm{L}$ & 525 & 922 \\
$\mathrm{Na}^{+}$ & $\mathrm{mmol} / \mathrm{L}$ & 0.18 & 7.7 \\
$\mathrm{~K}^{+}$ & $\mathrm{mmol} / \mathrm{L}$ & 0.02 & 0.40 \\
$\mathrm{Ca}^{2+}$ & $\mathrm{mmol} / \mathrm{L}$ & 1.9 & 1.1 \\
$\mathrm{Mg}^{2+}$ & $\mathrm{mmol} / \mathrm{L}$ & 1.4 & 0.97 \\
$\mathrm{Cl}^{-}$ & $\mathrm{mmol} / \mathrm{L}$ & 0.40 & 4.1 \\
$\mathrm{NO}_{3}^{-}$ & $\mathrm{mmol} / \mathrm{L}$ & 0.25 & $<1.6 \cdot 10^{-3}$ \\
$\mathrm{SO}_{4}^{2-}$ & $\mathrm{mmol} / \mathrm{L}$ & 0.13 & 0.21 \\
$\mathrm{HCO}_{3}^{-}$ & $\mathrm{mmol} / \mathrm{L}$ & 5.7 & 7.7 \\
$\mathrm{CH}_{4}$ & $\mathrm{mmol} / \mathrm{L}$ & $\mathrm{ND}$ & 2.2 \\
$\mathrm{~N}_{2}$ & $\mathrm{mmol} / \mathrm{L}$ & $\mathrm{ND}$ & 0.95 \\
$\mathrm{Bubble}^{-}$ & $\mathrm{ND}$ & 2.93 \\
\hline
\end{tabular}


The TDS of the tap water used for the heat storage test is $525 \mathrm{mg} / \mathrm{L}$. The water is described as $\mathrm{Ca}-\mathrm{Mg}-\mathrm{HCO}_{3}$-type. The $\mathrm{Ca} / \mathrm{Mg}$-ratio is 1.4 . Again this points to a mainly dolomitic aquifer from which the water was produced. The hydrogeochemical calculations showed that the tap water is within the quasi-equilibrium with respect to calcite $(\mathrm{SI}=-0.2)$ at $10{ }^{\circ} \mathrm{C}$. Nevertheless, heating the tap water up to $110^{\circ} \mathrm{C}$ results in a $\mathrm{SI}_{\text {calcite }}$ of 0.97 (ninefold supersaturation) and in a $\mathrm{SI}_{\text {dolomite }}$ of 1.55 (35-fold supersaturation). To prevent precipitation of carbonates in the heat exchangers and pipes, the water needs to be conditioned prior to heating.

The same applies to the reservoir water which is going to be used as working fluid during operation. Heating the unconditioned aquifer water up to $130{ }^{\circ} \mathrm{C}$ would result in a SI of 1.2 for calcite and 1.6 for dolomite.

The different hydrochemical composition of the reservoir water and the injected tap water turned out to be very useful for the interpretation of the field experiment. Not only can the hydrochemical contrast of ion concentrations, for example, sodium, be used as an intrinsic conservative tracer during the test. The different types of water also allow an extrapolation to facilities where the boreholes explore a different lithostratigraphic setting.

\section{Conditioning of the injected tap water}

The amount of $\mathrm{CO}_{2}$ to prevent precipitation of the tap water during heating was calculated for a target SI for calcite of 0.1-0.2 at the corresponding temperature. A slight oversaturation was intentional, to reduce corrosion of the pipe materials and later dissolution effects which come with lower temperatures in the reservoir. The calculated $\mathrm{CO}_{2}$ concentration was in a range of $0.09 \mathrm{~g} / \mathrm{L}$ at $65^{\circ} \mathrm{C}$ and $0.42 \mathrm{~g} / \mathrm{L}$ at $110{ }^{\circ} \mathrm{C}$. The calculated $\mathrm{pH}$ value of the tap water after addition and complete dissolution of $\mathrm{CO}_{2}$ was in a range of 6.78 at $65^{\circ} \mathrm{C}$ to 6.22 at $110{ }^{\circ} \mathrm{C}$.

On site measurements showed consistently higher $\mathrm{pH}$ values compared to the calculated values. This indicates that $\mathrm{CO}_{2}$ did not dissolve completely at the point of measurement. During operation of the ATES this effect has to be taken into account before using the $\mathrm{pH}$ valve for controlling $\mathrm{CO}_{2}$ addition, either by applying a correction factor or by placing the $\mathrm{pH}$ probe further away from the $\mathrm{CO}_{2}$ injection thus allowing more time for $\mathrm{CO}_{2}$ dissolution.

The efficiency of the $\mathrm{CO}_{2}$ addition to prevent precipitation during heating was confirmed after dismantling the heat exchangers and pipes, which did not show any precipitates or signs of corrosion after a total injection volume of $13,600 \mathrm{~m}^{3}$.

\section{Development of temperature, pressure, $\mathrm{pH}$, and electrical conductivity}

The temperature development at the well head is shown in Fig. 6. After reverting the flow direction, the curves start with a sharp increase as the produced water fills the bypass where the parameters are recorded. This is immediately followed by a decrease after the water from the upper borehole (total volume of $22 \mathrm{~m}^{3}$ ) has been produced. Afterwards, the temperature decreases slowly. The temperature level reached after $36 \mathrm{~h}$ of production rises with increasing injection temperatures. There is also a $\Delta T$ of $3.4^{\circ} \mathrm{C}$ from stage 3 to stage 4, which can be explained by the higher temperatures of the rock matrix after the fourth cycle and proves the "charging" of the ATES. 


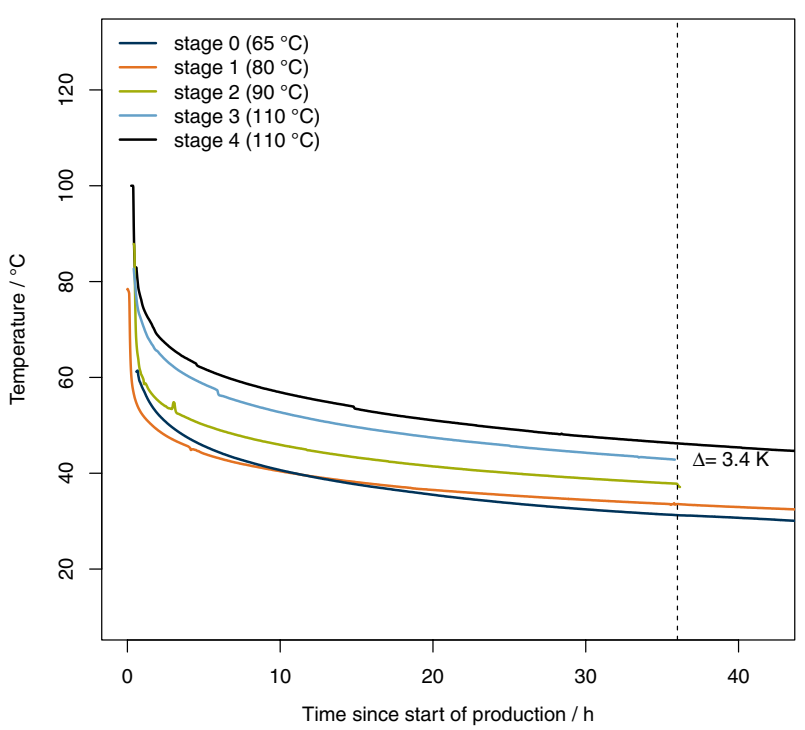

Fig. 6 Development of the temperatures during production stages

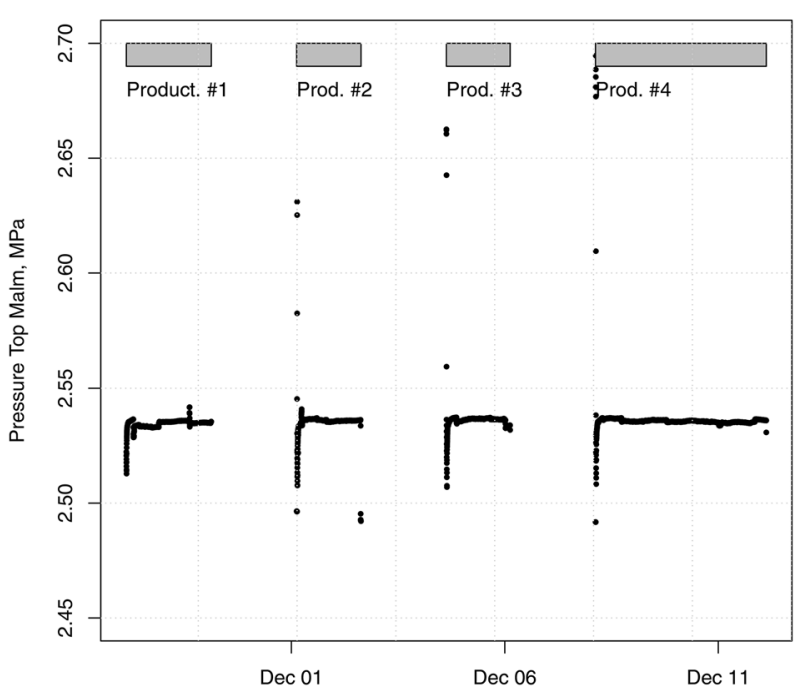

Fig. 7 Development of the pressure at top Malm. Grey bars indicate production stages 1-4

The pressure at the top of the aquifer was constant at $2.53 \mathrm{MPa}$ during the production stages (see Fig. 7). There are no indications of a sudden increase in pressure. There is also no decrease of the injection pressure which could have been expected because of a decrease in viscosity of the hot water in the reservoir. The experimental data suggest that the effects of viscosity are negligible in this setting and lead to the assumption of rather large flow paths.

Figure 8 shows the development of the $\mathrm{pH}$ values during production. There is a general increase from the first to the last production stage. This makes sense and reflects the reaction kinetics in the aquifer. The level of the $\mathrm{pH}$ value reflects the amount of $\mathrm{CO}_{2}$ which was added to prevent scalings. At higher temperatures, the amount 


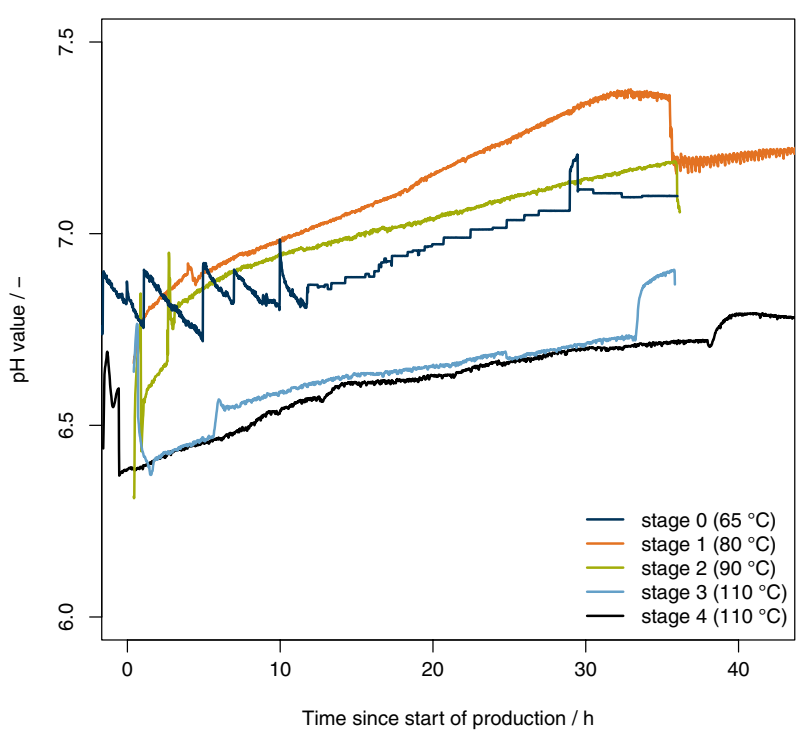

Fig. 8 Development of the $\mathrm{pH}$ values during production stages

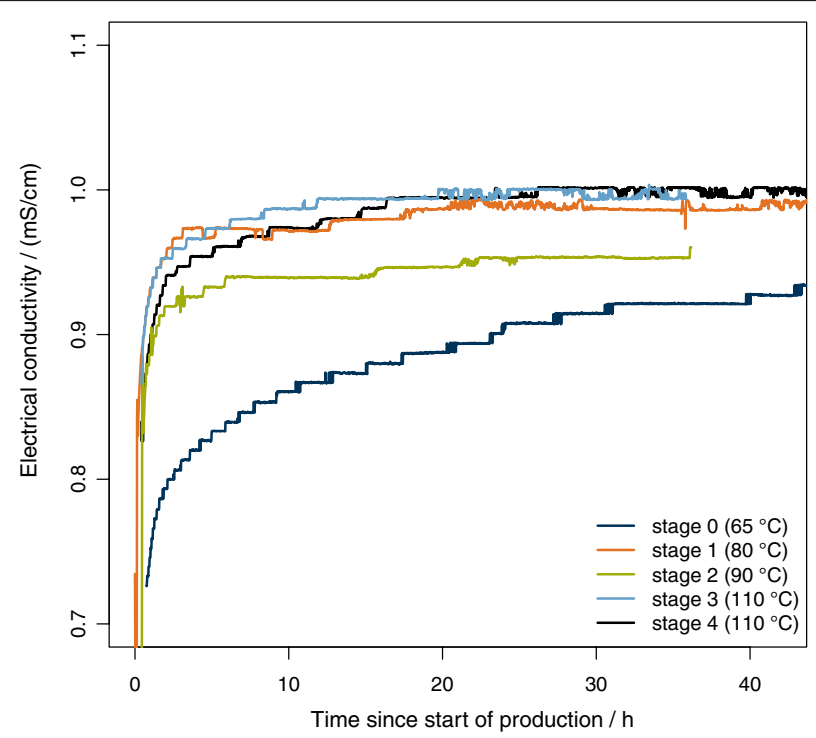

Fig. 9 Development of the electrical conductivity during production stages

increased and the $\mathrm{pH}$ value decreased. With higher temperatures in the aquifer, equilibrium was established at a lower level.

The absolute values of stage 0 are lower than those of stages 1 and 2 although the injection temperature was lower. This could be explained by the higher proportioning of $\mathrm{CO}_{2}$ in stage 0 , but could also indicate different matrix conditions. In stage 0 , only the top part of the aquifer was directly accessible from the borehole.

The development of the EC shows a monotonic, but stepwise increase. The steps are caused by the resolution of the analog-digital converter of the electrode (see Fig. 9). After starting production, EC increased immediately from $0.64 \mathrm{mS} / \mathrm{cm}$ (EC of tap water) to $0.97 \mathrm{mS} / \mathrm{cm}$. Stages 0 and 2 show a slower increase. The increase in EC could point 
to dissolution of the rock matrix as well as to mixing of the injected water with the reservoir water $(\mathrm{EC}=1.1 \mathrm{mS} / \mathrm{cm})$. The former can be explained by undersaturation of the injected water with respect to calcite and dolomite as the injected water is cooling down in the reservoir.

The hydrogeochemical model calculation indicates that the increase in EC is equivalent to a dissolution of roughly $250 \mathrm{mg} / \mathrm{L}$ calcite. This seems rather high and indicates that dissolution alone does not account for the full increase in EC. The hydrochemical data (see below) supports a mixing of the injected tap water with reservoir water, which adds to the increase in EC.

\section{Development of hydrochemical composition}

The development of the sodium ion concentration during stage 0 is shown in Fig. 10a and during stages 1-4 in Fig. 10b. The sodium ion concentration rises sharply after the production started. The sodium ion concentration in tap water is $4 \mathrm{mg} / \mathrm{L}$, and the concentration of the reservoir water is $156 \mathrm{mg} / \mathrm{L}$ (depth of well design: $297 \mathrm{~m} \mathrm{TVD}$ ) resp. $177 \mathrm{mg} / \mathrm{L}$ (depth of well design: $473 \mathrm{~m}$ TVD). Thus, the development of sodium ions serves like an additional chemical tracer that represents the influx of the reservoir water. The development of the sodium ion concentration for each stage can be described as a single exponential growth. The fit parameters represent the initial conditions and the dilution or influx rate. Similar behavior can be seen in the development of other ion concentrations, e.g., the potassium ion concentrations.

Figure 10c, $\mathrm{d}$ show the development of the calcium and Fig. 10e, $\mathrm{f}$ the magnesium ion concentrations during the stage 0 (c, e) and during stages 1-4 (d, f). Calcium and magnesium ion concentrations of the injected tap water are about $35 \mathrm{mg} / \mathrm{L}$ resp. $10 \mathrm{mg} / \mathrm{L}$ higher than the concentration of the reservoir water (see blue and green lines). The calcium ion concentrations of stages 0,3 and 4 exceed the concentrations of the injected tap water about $10-15 \mathrm{mg} / \mathrm{L}$ and decrease exponentially to the reservoir water concentrations. These maximum concentrations suggest dissolution processes of the aquifer matrix. The calcium ion concentration for stage 1 and 2, as well as the magnesium ion concentration, decrease similarly over production time. On the long term, they are likely to reach the concentration of the reservoir water.

Due to the described mixing processes, a mass balance based on the measured concentrations alone would be misleading. Thus, the mass balance requires the hydrogeochemical model which is presented later.

\section{Energy balance}

The calculated thermal energy stored and recuperated throughout the test is shown in Fig. 11. One has to keep in mind, that the production times were shorter than the injection times for stages 1-3 to avoid the production of mixed water from the fringes of the injected volume. Therefore, the recuperated energy has to be significantly lower for stages $1-3$.

The overall energy balance of the heat storage test (stages $1-4$, injected water volume = produced water volume) is $48 \%$. This is acceptable in terms of "charging" the reservoir, i.e. heating up the reservoir matrix to reduce energy losses at later stages. 

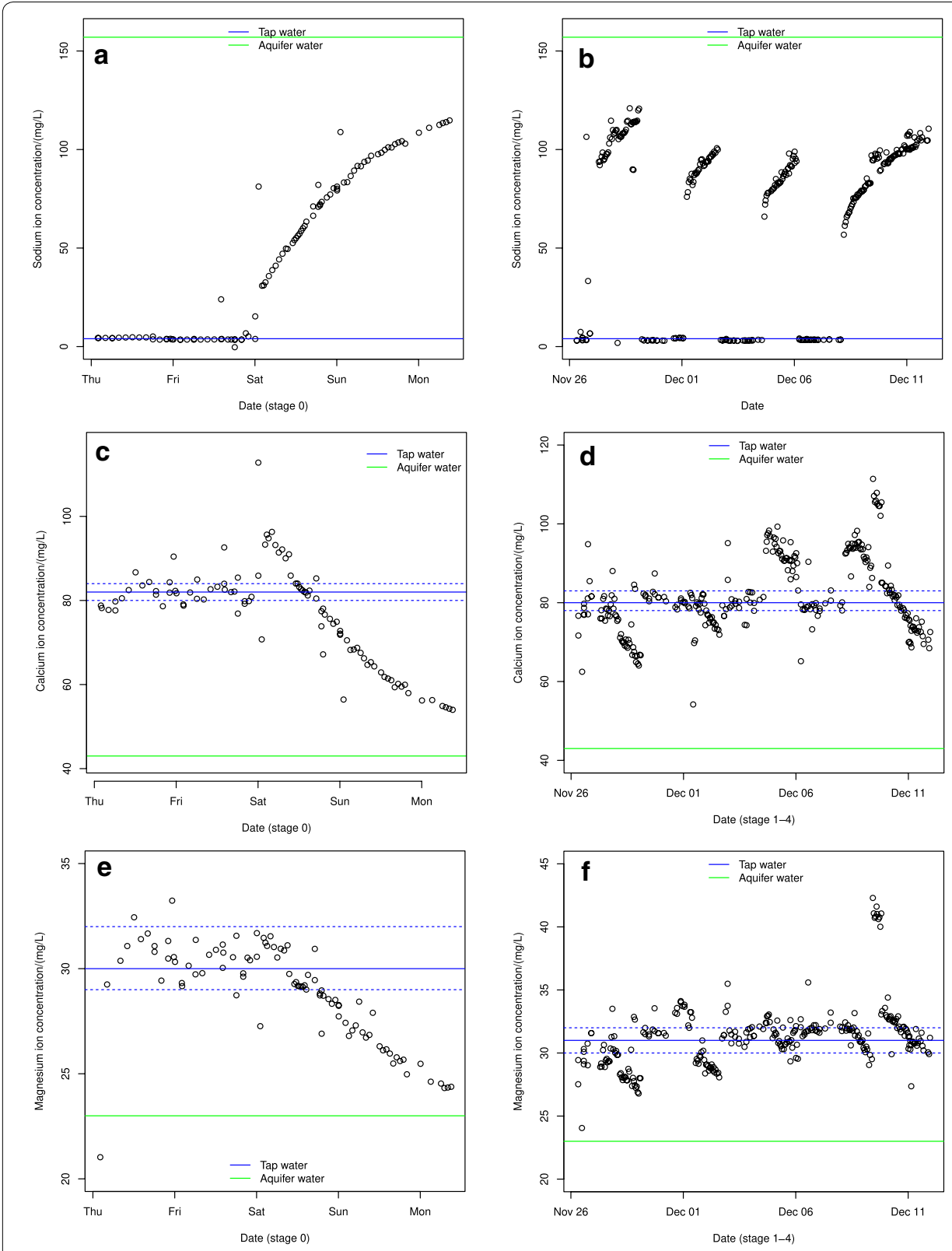

Fig. 10 Development of the sodium ion concentrations during stage 0 (upper left: a) and during stages 1-4 (upper right: b), calcium ion concentrations during stage 0 (middle left: $\mathbf{c}$ ) and during stages 1-4 (middle right: $\mathbf{d}$ ) and magnesium ion concentrations during stage 0 (bottom left: e) and during stages 1-4 (bottom right: $\mathbf{f}$. The reservoir water concentration is shown as a green line and the median of the injected tap water as a blue line ( 25 and $75 \%$ quantile is shown as a dashed blue line). The samples were taken at the bypass (see Fig. 2)

Comparing similar time periods in stages $1-4$, the ratio of the recuperated energy increases with each heating cycle, which also shows that the aquifer matrix is heated to an elevated temperature.

The delivered thermal power ( $1 \mathrm{MW}$ at the end of stage 4 ) is poor compared to the injected power of $5.5 \mathrm{MW}$ (at $110^{\circ} \mathrm{C}$ and $15 \mathrm{~L} / \mathrm{s}$ ) (see Fig. 12). In addition, the temperature levels are low compared to the temperature levels required for the technical 


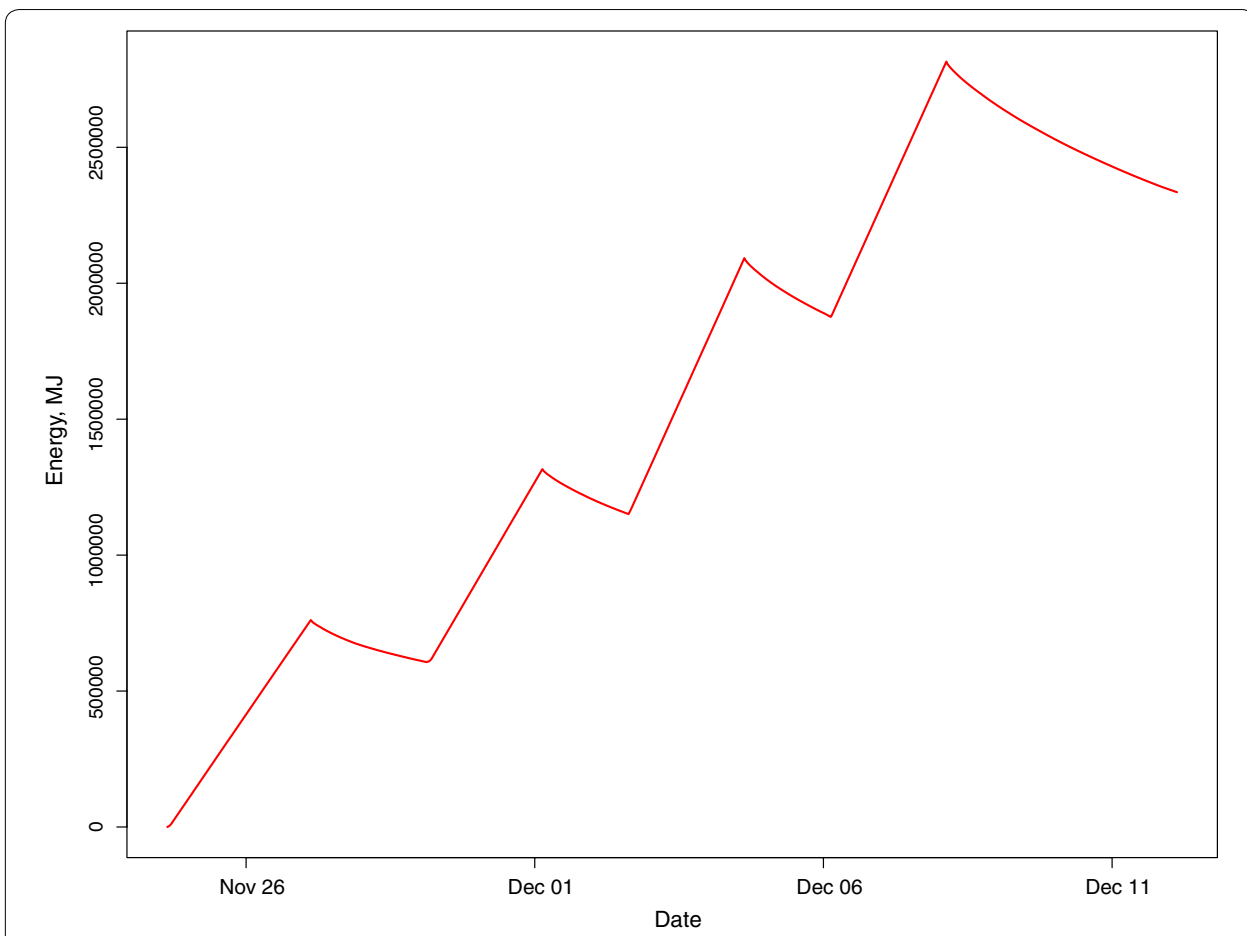

Fig. 11 Comparison of injected and recovered energy during the heat storage test

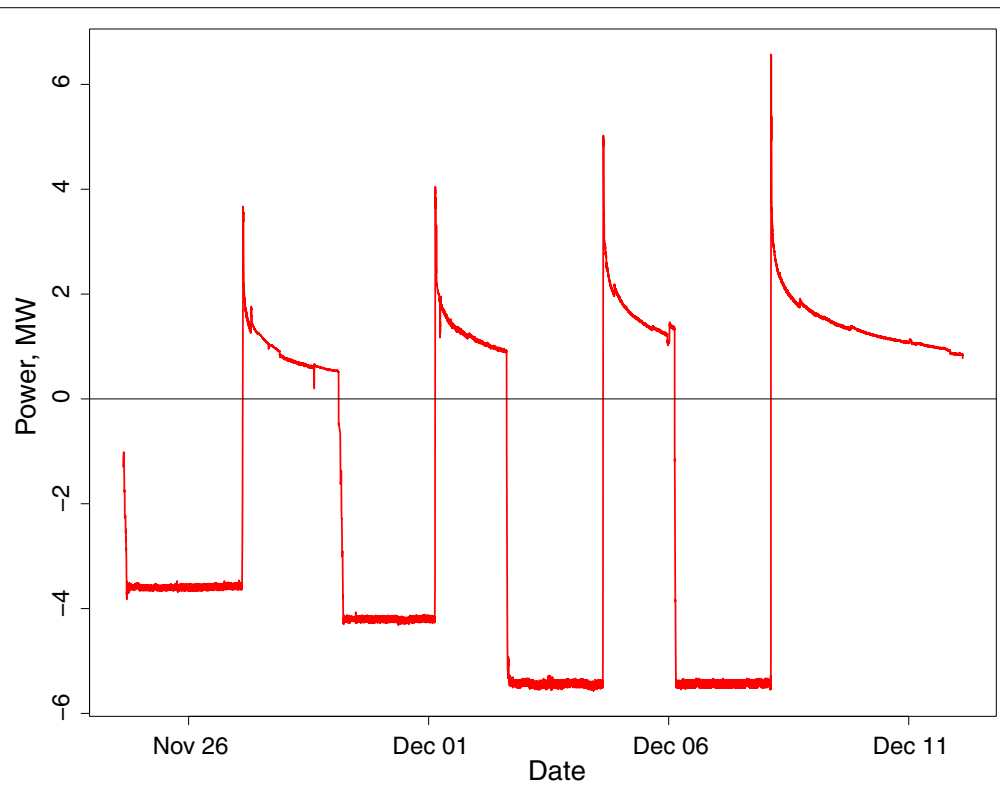

Fig. 12 Comparison of injected and recovered power during the heat storage test

processes at the facility. This came to no surprise and will improve significantly, once the reservoir matrix has reached its operating temperature. The energy balance indicates that several heating cycles will be necessary before the aquifer storage system can be run efficiently. 
The energy balance and power delivery seem to be strongly affected by the assumed mixing processes in the reservoir. This effect was not encountered before and was not included into the preliminary models. Both immediate consequences of the mixing, reduction of the temperature and an incomplete recovery of the injected water, lead to a lower energy balance and lower power output.

\section{Quantification of mixing effects on energy balance and power delivery}

The very high transmissivity and negligible effects of viscosity and dissolution suggest unusually large flow paths. This promotes density-driven flow and mixing in the aquifer. The operation of the storage site, on the other hand, is planned with flow rates of $80 \mathrm{~L} / \mathrm{s}$ and an injection interval of 6-8 months. Consequently, the hydraulic contrast will be higher, leading to a more uniform flow around the well and less mixing.

Mixing effects were compensated in order to calculate the development of the produced temperatures without the influx of the cold reservoir water. The amount of reservoir water in the produced and analysed water was calculated from the hydrochemical contrast of the sodium ion concentration between reservoir water and tap water. The increase in the sodium ion concentrations nicely follows an exponential function, which indicates a constant mixing rate. This function was used to calculate corrected temperatures by subtracting the lower temperatures of the reservoir water. This procedure intrinsically reduces changing mixing ratios in later stages caused by leftover mixed water from the previous stages.

Figures 13 and 14 show the effects of the correction: measured temperatures at the end of stage 0 were $31{ }^{\circ} \mathrm{C}$ and increased to $46^{\circ} \mathrm{C}$ after compensation of mixing with cold reservoir water. Figure 15 shows the corrected temperature development of selected stages. Subtraction of the cold reservoir water influence results in an increase of about $15{ }^{\circ} \mathrm{C}$ for all successful corrected stages. $\Delta T$ raised to $4.1^{\circ} \mathrm{C}$ from stage 3 to stage 4 .

The applied compensation is also useful to transfer the results to systems with lower transmissivity, more radially symmetric flow and mixing only at the fringes of the

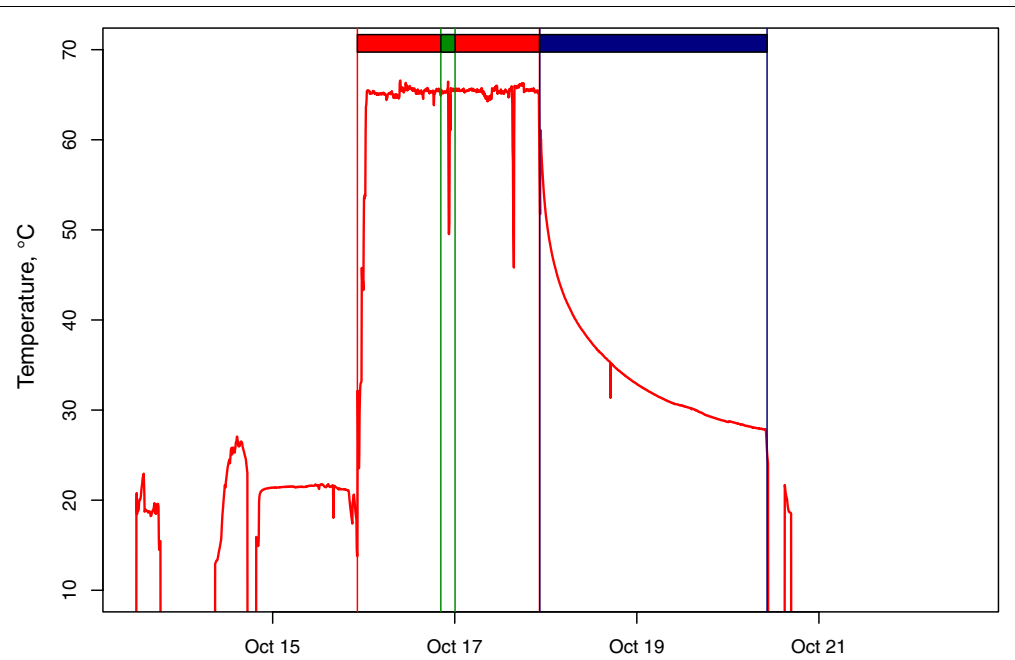

Fig. 13 Development of the temperatures during production stage $0\left(T_{\operatorname{lnj}}=65^{\circ} \mathrm{C}\right)$. The colored bars at the top symbolize injection (red), calibration of the probe (green) and production (blue) stage 


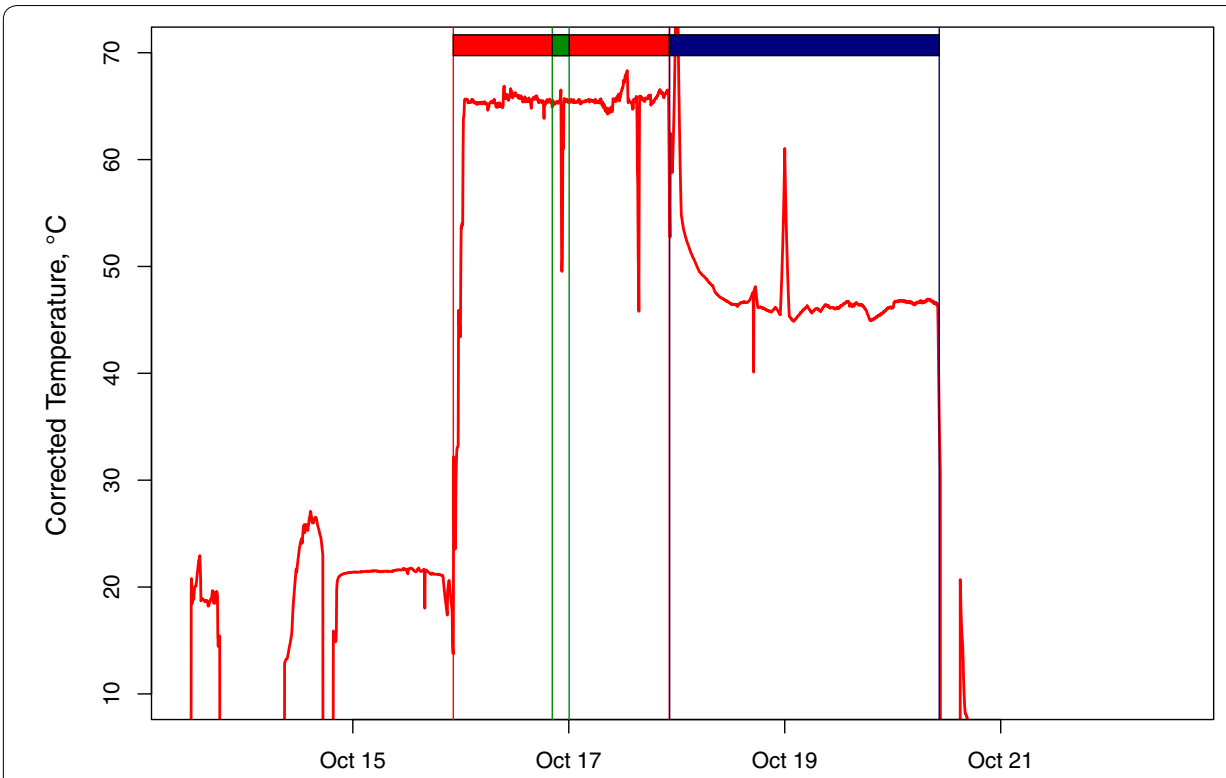

Fig. 14 Temperatures corrected with the cold reservoir influx by means of the development of the sodium ion concentrations during production stage $0\left(T_{\operatorname{lnj}}=65^{\circ} \mathrm{C}\right)$. The colored bars at the top symbolize injection (red), calibration of the probe (green) and production (blue) stage

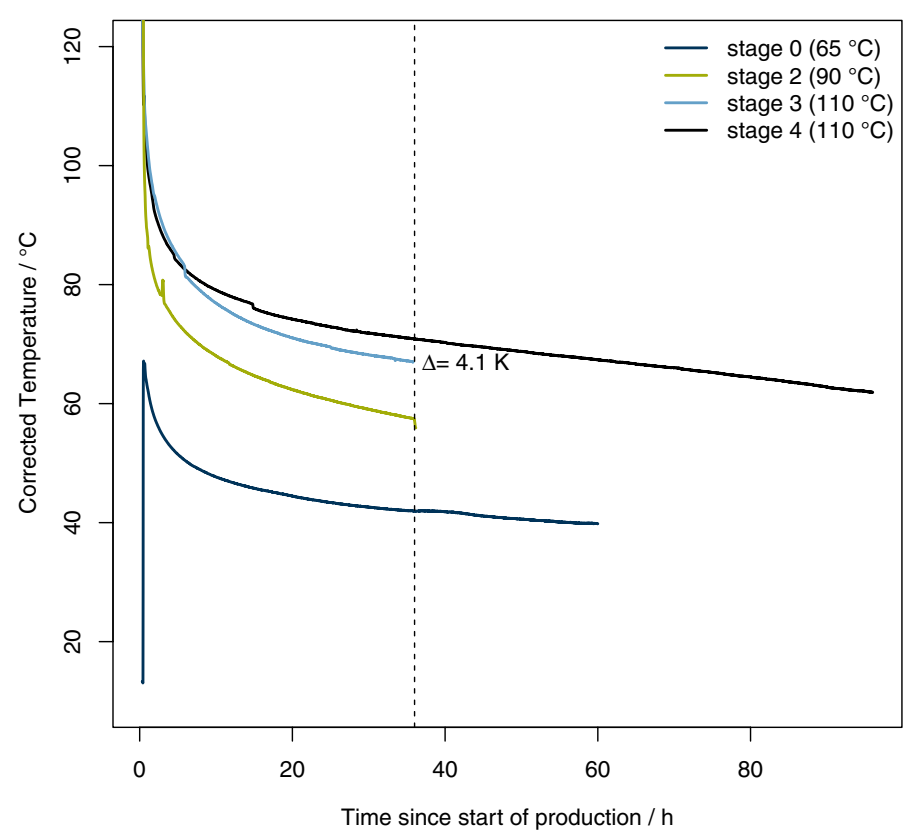

Fig. 15 Development of the corrected temperatures during production stages 0-4 (corrected by fitted sodium ion concentrations) 
injected volume. This more standard case, which was initially assumed for the test site as well, will then deliver higher power and better recovery at an earlier stage.

\section{Quantification of dissolution processes in the reservoir}

Figure 16 shows the simulation results of the four main stages of the heat storage test (lines) vs. the measured sodium, calcium and magnesium ion concentrations as well as the temperature development. The sodium ion concentration and the temperature development are simulated precisely and reflect perfectly the measured concentrations. That supports the overall ability to simulate a reactive system by a simplified transport model with PhreeqC based on temporal resolution.

The simulation of calcium and magnesium ion concentration is more complex, since kinetic reactions of the carbonate aquifer matrix have to be taken into account and the agreement of measured and simulated concentrations varies due to the implemented reaction rates and due to the reactive surface in the aquifer. Nevertheless, calcium and magnesium ion concentrations can be assessed very well by the given approaches. In stage 3 , the simulated calcium ion concentrations are significantly lower compared to the measured concentrations immediately after the start of production.

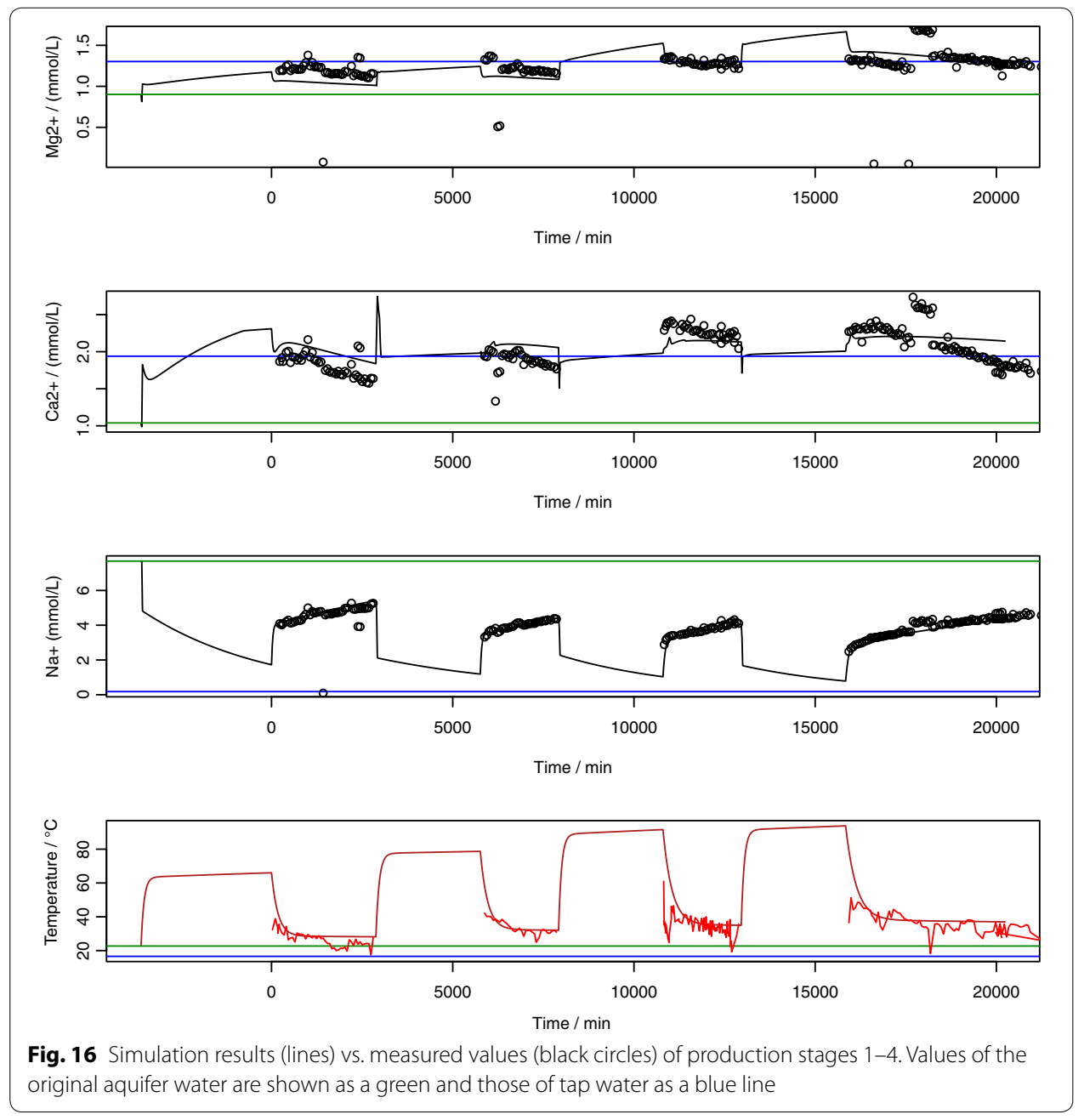


The simulation results match the experimental data qualitatively and, with one exception, quantitatively. Based on the simulation, the dissolved mass of aquifer matrix is $850 \mathrm{~kg} \mathrm{CaCO}_{3}$ and $190 \mathrm{~kg} \mathrm{CaMg}\left(\mathrm{CO}_{3}\right)_{2}$ within $414 \mathrm{~h}$ of the heat storage test.

While the model reached an excellent agreement to measured data, the intrinsic ambiguity of this type of model remains. As the dissolution and precipitation rates are the product of rate constant multiplied with the reactive area, only the overall rates can be derived from the measured ion concentrations.

\section{Hydrochemical modelling of an aquifer thermal energy storage system}

The standard setting for an ATES system consists of two wells connected to a doublet system. In our simulation scenario, cold water is produced during summer months, heated up by excess heat to $130{ }^{\circ} \mathrm{C}$ and injected with a flow rate of $80 \mathrm{~L} / \mathrm{s}$ in the hot well (see Fig. 3). After an injection time of up to eight months, the water is produced to extract the heat down to temperatures of $60{ }^{\circ} \mathrm{C}$. The water is now oversaturated with respect to $\mathrm{CO}_{2}$ and undersaturated with respect to the aquifer matrix and injected in the cold well. As a consequence dissolution of the aquifer matrix takes place around the cold well.

Table 3 shows the increase in $\mathrm{CO}_{2}$, TDS and dissolved aquifer matrix for the first and second year, assuming a mixed aquifer matrix (limestone and dolomite). The necessary amount of $\mathrm{CO}_{2}$ to prevent precipitation during heating is $0.72 \mathrm{~g} / \mathrm{L}$ in the first year and $4.4 \mathrm{~g} / \mathrm{L}$ in the second year.

Thus, with each additional storage cycle more $\mathrm{CO}_{2}$ is necessary to prevent scaling. Modelling results with inorganic acids show a similar trend. By adding complexing agents the expected number of cycles can be increased slightly. However, this conditioning of the ATES working fluid not only meets strong resistance by authorities and NGOs but also requires high amounts of complexing agents.

Removal of excess $\mathrm{CO}_{2}$ from the injected cold water by stripping might extend the time frame for operation. The simulations show that five tons of $\mathrm{CO}_{2}$ per day have to be stripped at the planned volumetric flow rates of $80 \mathrm{~L} / \mathrm{s}$. Because there is no technical solution to store these amounts of $\mathrm{CO}_{2}$, it has to be released into the atmosphere and contradicts the character of the CHP-ATES combination.

To overcome these problems, we suggest a triplet setup which is depicted in Fig. 5. Here, the water is produced from a cold well, conditioned, heated and injected into the hot well. From here, the water is produced in times of increased heat demand and, after recuperation of the heat, is injected into a third "warm" well. From the "warm"

Table 3 Required amount of $\mathrm{CO}_{2}$, increase in TDS and matrix dissolution from the first to the second year, assuming mixed aquifer matrix (calcite and dolomite)

\begin{tabular}{llc}
\hline Parameter & First year & Second year \\
\hline $\mathrm{CO}_{2}, \mathrm{~g} / \mathrm{L}$ & 0.72 & 4.40 \\
$\mathrm{TDS}, \mathrm{mg} / \mathrm{L}$ & 890 & 1317 \\
Dissolved matrix, $\mathrm{mg} / \mathrm{L}$ & 0.18 & 321 \\
$\mathrm{CaCO}$ and CaMg $\left(\mathrm{CO}_{3}\right)_{2}$ & & \\
\hline
\end{tabular}


injection well, the water will slowly propagate to the "cold" production well. Although we calculated a slight increase in the hardness of the water, model results show that this operation can be run for decades.

Optimal energy efficiency in the triplet setup requires state-of-the-art low enthalpy heating systems and heat pumps because the temperature difference between the water at the "cold" well and the injected water into the "warm" well will be lost. While this is an issue for the test site with a temperature of $22{ }^{\circ} \mathrm{C}$ at the cold well, ATES in the Munich area will hardly suffer from this energy loss because the initial temperatures are already at $60^{\circ} \mathrm{C}$ and higher.

\section{Conclusion}

The heat storage test underlined the importance of high-resolution hydrochemical monitoring and modelling in the planning and testing of ATES operations. It was able to explain the low temperatures during the heat storage test with mixing processes in the aquifer. The low energy recovery of $48 \%$ did not meet the expectations and were lower than the predicted temperatures calculated with a 3D finite element heat storage model (Bartels et al. 2015). It would also have caused longer or more "charging" cycles because the mixing increases the virtual volume of the ATES system.

Hydrochemical data showed that the cores from the borehole do not reflect the lithostratigraphic setting in the vicinity of the borehole. While the cores in the upper, highly permeable part of the aquifer were showing a limestone matrix, the hydrochemical composition of the water from the aquifer has a $\mathrm{Ca} / \mathrm{Mg}$ ratio of 1 , indicating that the matrix along the flow paths leading to the borehole is composed of dolomites and that the limestone has to be local with a very limited spatial extent.

The hydrogeochemical modelling with PhreeqC proved to be reliable, both for calculating the amount of $\mathrm{CO}_{2}$ which has to be added to the cold water before the heat exchanger to prevent precipitation, and for quantifying the reactions of the injected water with the aquifer matrix. The forward simulations with this validated model concept show that a doublet system in carbonates with one "hot" storage well, which receives the hot water and one "cold" storage well, which receives the cold water after the thermal energy has been recuperated, works only for a few cycles. This is caused by the supersaturation of $\mathrm{CO}_{2}$ in the cold water (after the heat is extracted) which leads to a strong dissolution of the aquifer matrix, and therefore, an enrichment in water hardness. We suggest a triplet system at this location, which can be run for decades. Here, the hardening takes place in a third "warm" borehole, and this water will not be produced as working fluid for the next heating cycle.

\section{Authors' contributions}

MU planned, organised, and performed the experiments, data acquisition, evaluation, graphical representation, and hydrogeochemical modelling. TB had the idea and did the conceptual design and planning for the heat storage test, developed the PhreeqC model, designed and implemented the evaluation routines. Both authors read and approved the final manuscript. 
we want to thank all responsible authorities for their administrative support and open mindedness and the representatives of BMW Group, especially M. Auer, H. Eichinger and F. Harlander for their initiative.

\section{Competing interests}

The authors declare that they have no competing interests.

\section{Availability of data and materials}

The datasets used and analysed during the current study are available from the corresponding author on reasonable request.

\section{Funding}

This work was funded by the Bavarian Ministry of Economic Affairs, Energy and Technology and the BMW Group.

\section{Publisher's Note}

Springer Nature remains neutral with regard to jurisdictional claims in published maps and institutional affiliations.

Received: 23 July 2018 Accepted: 24 January 2019

Published online: 06 February 2019

\section{References}

Andersson O. Thermal energy storage for sustainable energy consumption: fundamentals, case studies and design. In: Aquifer thermal energy storage (ATES). Dordrecht: Springer Netherlands; 2007. p. 155-76. https://doi. org/10.1007/978-1-4020-5290-3_8.

Appelo CAJ, Postma D. Geochemistry. Groundwater and pollution. Amsterdam: A.A: Balkema Publishers; 2005.

Bartels J, Baumann T, Bohnsack D, Huber B, Schubert A, Steiner U, Ueckert M, Wenderoth F, Zosseder K. Forschungsvorhaben Hochtemperatur Aquiferspeicher Schlussbericht Phase 1. Tech. rep.: Eine Kooperation der Aquasoil GmbH, Erdwerk GmbH und Technischen Universität München; 2015.

Baumann T, Bartels J, Lafogler M, Wenderoth F. Assessment of heat mining and hydrogeochemical reactions with data from a former geothermal injection well in the Malm aquifer, Bavarian Molasse Basin, Germany. Geothermics. 2017;66:50-60. https://doi.org/10.1016/j.geothermics.2016.11.008.

Deutsches Institut für Normierung (DIN). Prüfung von gasförmigen Brennstoffen und sonstigen Gasen - Bestimmung des Gehaltes an Schwefelverbindungen - Teil 4: Gehalt an Schwefelwasserstoff, Zinkacetat-Verfahren, $\mathrm{H}_{2}$ S. 1995.

Dorsch K, Pletl C. Bayerisches Molassebecken - Erfolgsregion der Tiefengeothermie in Mitteleuropa. Geothermische Energie Heft. 2012;73:14-8.

Drijver B, van Aarssen M, de Zwart B. High-temperature aquifer thermal energy storage (HT-ATES): sustainable and multiusable. In: Innostock 2012-the 12th international conference on energy storage 2012.

Fritzer T, Settles E, Dorsch K. Bayerischer Geothermieatlas. Bayerisches Staatsministerium für Wirtschaft und Medien, Energie und Technologie: Tech. rep; 2014.

Gautelier M, Schott J, Oelkers EH. An experimental study of dolomite dissolution rates at $80{ }^{\circ} \mathrm{C}$ as a function of chemical affinity and solution composition. Chem Geol. 2007;242(3-4):509-17. https://doi.org/10.1016/j.chemg eo.2007.05.008

Hartog N, Drijver B, Dinkla I, Bonte M. Field assessment of the impacts of aquifer thermal energy storage (ates) systems on chemical and microbiological groundwater composition. In: European geothermal conference 2013. 2013.

Kranz S, Blocher G, Saadat A. Improving aquifer thermal energy storage efficiency. In: Proceedings world geothermal congress 2015, Melbourne, Australia. 2015.

Langmuir D. The geochemistry of some carbonate ground waters in central pennsylvania. Geochem Cosmochim Acta. 1971;35(10):1023-45. https://doi.org/10.1016/0016-7037(71)90019-6.

Lee KS. A review on concepts, applications, and models of aquifer thermal energy storage systems. Energies. 2010;3(6):1320-34. https://doi.org/10.3390/en3061320.

Lee KS. Underground thermal energy storage. In: Aquifer thermal energy storage. London: Springer London; 2013. p. 59-93. https://doi.org/10.1007/978-1-4471-4273-7.

Lira C. Preos.xls (for use with an introduction to applied thermodynamics by j.r. elliott and c.t. lira). Tech. rep., 1997. http:// www.egr.msu.edu/lira/thermtxt.htm, Aufgerufen am 28 Mar 2016.

Mayrhofer C, Niessner R, Baumann T. Hydrochemistry and hydrogen sulfide generating processes in the Malm aquifer, Bavarian Molasse Basin, Germany. Hydrogeol J. 2014;22(1):151-62. https://doi.org/10.1007/s10040-013-1064-2.

Parkhurst D, Appelo C. Description of input and examples for phreeqc version 3-a computer program for speciation, batch-reaction, one-dimensional transport, and inverse geochemical calculations. Tech. rep., URL http://pubs.usgs. gov/tm/06/a43/. 2013.

Perlinger JE, Almendinger JE, Urban NR, Eisenreich SJ. Groundwater geochemistry of aquifer thermal energy storage: long-term test cycle. Water Resour Res. 1987;23(12):2215-26. https://doi.org/10.1029/WR023i012p02215.

Plummer N, Wigley T, Parkhurst D. The kinetics of calcite dissolution in $\mathrm{CO}_{2}$-water systems at 5 to $60{ }^{\circ} \mathrm{C}$ and 0.0 to 1.0 atm $\mathrm{CO}_{2}$. Am J Sci. 1978;278:179-216. https://doi.org/10.2475/ajs.278.2.179.

Pokrovsky OS, Schott J. Kinetics and mechanism of dolomite dissolution in neutral to alkaline solutions revisited. Am J Sci. 2001;301:597-626.

Sanner B, Kabus F, Seibt P, Bartels J. Underground thermal energy storage for the German parliament in Berlin, system concept and operational experiments. In: Proceedings world geothermal congress 2005, Antalya, Turkey. 2005. 
Schout G, Drijver B, Gutierrez-Neri M, Schotting R. Analysis of recovery efficiency in high-temperature aquifer thermal energy storage: a Rayleigh-based method. Hydrogeol J. 2014;22(1):281-91. https://doi.org/10.1007/s1004 0-013-1050-8.

Stober I, Bucher K. Geothermie-2. Auflage. In: Wärmestransport und thermische Parameter. Berlin: Springer Spektum; 2014. p. 9-14. https://doi.org/10.1007/978-3-642-41763-4.

Stober I, Fritzer T, Schulz R. Deep geothermal energy. In: Principles of deep geothermal energy. Berlin: Federal Ministry for Economic Affairs and Energy, BMWi; 2014. p. 7-15.

Ueckert M. Hochtemperaturaquiferspeicher in den Malmcarbonaten des bayerischen Molassebeckens. PhD thesis, TUM. 2016

Ueckert M, Niessner R, Baumann T. High temperature aquifer storage. In: Proceedings, 41st workshop on geothermal reservoir engineering Stanford University, Stanford, California, February 22-24, 2016. 2016.

Submit your manuscript to a SpringerOpen ${ }^{\circ}$ journal and benefit from:

- Convenient online submission

- Rigorous peer review

- Open access: articles freely available online

- High visibility within the field

- Retaining the copyright to your article

Submit your next manuscript at $\gg$ springeropen.com 